\title{
Concentration and Distribution of Uranium in Mytilus edulis and Associated Materials
}

\author{
E. I. Hamilton \\ Natural Environment Research Council, Institute for Marine Environmental Research, Prospect Place, The Hoe, Plymouth \\ PL1 3DH, United Kingdom
}

\begin{abstract}
Concentration and distribution of uranium in the mussel Mytilus edulis are described for sampling sites in the United Kingdom near and distant from sources of nuclear effluents; the data reflect natural availability from the marine environment, any effect attributable to the proximity of nuclear effluent discharges being minimal. With the exception of uranium associated with food and particulate materials present in the digestive organ, the highest levels were found associated with byssal threads, the periostracum and the excretory organs. It has been observed that the tanning process associated with the development of byssal threads involves uranium which has a special affinity for SS-SH and disulphide groups in organs. The lowest concentrations of uranium were found in the periostracum-free shell. Depuration experiments have demonstrated that after a fairly rapid loss of uranium from the digestive gland, that which remains within organs and tissues is retained and is associated with the surfaces of organs and tissues. In the sediments uranium is enriched in the finer fraction but no evidence for an excessive enrichment arising from nuclear effluents was observed.
\end{abstract}

\section{INTRODUCTION}

There are very few data available for the concentration and distribution of uranium in marine biota. Those which are available describe occasional measurements of concentration factors in whole animals and some organs relative to levels in seawater. This study presents the results of a detailed investigation of the concentration and distribution of uranium in Mytilus edulis, and forms part of a larger investigation describing the uptake and subsequent distribution of the transuranium group of elements (plutonium, americium, curium and californium) in the mussel. Two groups of mussels have been investigated, one taken from the vicinity of the British Nuclear Fuel Ltd. (BNFL) complex off Windscale, Cumbria, U.K., where they are exposed to any uranium present in nuclear effluents discharged to the adjacent sea, and the other group collected from various sites in the U.K. which are associated with only natural sources of uranium. Data are also presented for the concentration and distribution of uranium and other elements in various biota and local sediments associated with the mussels' habitat.
In most mussels the gross distribution pattern of uranium may be described in terms of 'surface seeking' properties (Vaughan, 1973) together with an affinity for some types of proteins, cell surfaces and sites of tissue calcification. Active uptake of uranium by the mussel is mainly through diet but because of the conservative nature of uranium in seawater, entry into the body cavity across the gills must also occur; this organ also contains occluded particulate debris associated with the ctenidia. Gut absorption factors for uranium must vary depending upon the chemical forms present in diet and water; uranium taken up by the systematic circulation is excreted through the kidneys and the non-transferable component is lost through faeces or pseudofaeces. In the sea, uranium is ubiquitously present at a concentration of about $3 \mu \mathrm{g} \mathrm{kg}^{-1}$ and exists primarily in the form of the tricarbonatouranylate anion $\mathrm{UO}_{2}\left(\mathrm{CO}_{3}\right)_{3}{ }^{4-}$ : the quadrivalent form is largely associated with particulate matter while the hexavalent form is conservative in nature. The availability of either form of uranium to a sessile animal such as the mussel is dependent upon the total load of suspended material in the seawater. In turbid water $\mathrm{U}^{+4}$ may be more abundant than $\mathrm{U}^{+6}$ hence, depending upon the relative ease of entry of either form, seawater or particulate debris can constitute the major route of entry. 


\section{MATERIALS AND METHODS}

\section{Animals and Associated Materials}

Samples of sub-littoral Mytilus edulis (shell length 45-75 mm) were collected from anchor chains securing the main BNFL effluent pipe; littoral mussels were collected from the intertidal zone at the landward end of the effluent pipe and also from the Ravenglass Estuary some 6 miles to the south. Mussels not exposed to BNFL effluent were collected from a sub-littoral site at Porthcumo and littoral samples from Trebarwith Strand and the Lynher Estuary, Cornwall, U.K. (Fig. 1).

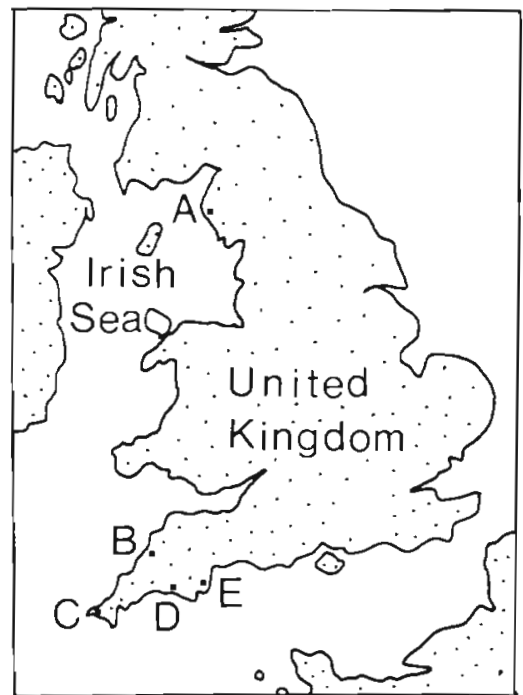

Fig. 1. Location of sampling sites. A: Windscale (BNFL), Seascale and Ravenglass Estuary; B: Trebarwith Strand; C: Porthcurno; D: Lynher Estuary; E: Teignmouth

All mussels were collected between January and November 1977 and returned to the laboratory alive where major organs and tissues were removed by dissection followed by freeze drying, homogenisation of aliquots in an agate grinder and the powder passed through a $38 \mu \mathrm{m}$ nylon sieve. At each site some mussels were retained in aquaria for additional experiments and histological examination. At each site other types of marine biota were also collected; for example barnacles, winkles and seaweed together with representative samples of surface sediment. Following dissection of $M$. edulis, occasional samples of the parasite Pinnotheres pisum (pea crab) were retained together with occasional samples of pearl found in the mantle and inner layer of the shell of $M$. edulis.

\section{Experimental Animals}

In order to examine the depuration of uranium in the laboratory, mussels were acclimated in a system of recirculating seawater, usually for up to $56 \mathrm{~d}$, although in one experiment the period was extended to $104 \mathrm{~d}$. The mussels were located at the bottom of an aquarium and, although faecal debris was periodically removed it did tend to accumulate in the tanks. The mussels were fed with Phaeodactylum tricornatum (5 I of algal culture for each 20-1 tank $24 \mathrm{~h}^{-1}$ ) by continuous administration.

\section{Histological and Cytological Examination}

Small pieces $\left(3-4 \mathrm{~mm}^{3}\right)$ of freshly excised organs were dropped into hexane at $-70^{\circ} \mathrm{C}$ and stored sealed until required for sectioning. Cryostat sections ( 3 and 7 $\mu \mathrm{m})$ were cut at a cabinet temperature of $-26^{\circ} \mathrm{C}$ in a Bright's Cryostat. For cytological examination, small pieces of tissue were fixed in Baker's formol-calcium $(+2.5 \% \mathrm{NaCl})$ for $24 \mathrm{~h}$ at $4{ }^{\circ} \mathrm{C}$ and then dehydrated in a descending dilution of absolute alcohol. For an examination of general histological structure, sections were stained by the Papanicolaou technique, the distribution of disulphide groups by the Performic AcidAlcian Blue Method and protein-bound SS-SH groups by the Modified Alkaline Tetrazolium Method. The determination of lysosomal activity as an index of stress was determined as described by Moore et al. (1978). In one of the analytical methods, namely assay for uranium by the fission track technique (see Analytical Methods) $7 \mu \mathrm{m}$ thick sections of organs were prepared on polycarbonate slides, the cover glass omitted and the thin sections covered with a polycarbonate detector (Hamilton, 1971).

In order to consider the distribution of uranium between the coarse and fine fractions of Ravenglass sediment, a representative sample was dried and sieved to provide greater and less than $20 \mu \mathrm{m}$ fractions; the concentration of uranium in each aliquot was determined by the delayed neutron method.

\section{Analytical Methods}

The analysis for total uranium was carried out by the delayed neutron method described by Amiel (1962) and Hamilton (1966); the distribution of uranium and other fissile nuclides, by the fission track method described by Hamilton (1978) using aliquots of dried tissue powder or thin sections of various tissues and organs. The uranium content of seawater was determined by the fission track method after acidification of $100 \mathrm{ml}$ of filtered $(0.45 \mu \mathrm{m})$ water, co-precipitation of uranium with aluminium phosphate and the preparation of a tablet of the dried powder which was then placed against a polycarbonate detector prior to neu- 
tron irradiation. In the fission track method Takiron polycarbonate was used and the sample together with the detector was irradiated by thermal neutrons in the AWRE Herald reactor Aldermaston (U. K.) to provide a track density of $2 \times 10^{6}$ tracks fission tracks $\mathrm{cm}^{-2}$ for a concentration of $I$ ppm $U$ in a thick source using an optical viewing magnification of $\times 320$. The delayed neutron and fission track methods are based upon the detection of events associated with nuclear fission processes; fissionable materials other than uranium (for example plutonium radionuclides) would, depending upon their respective neutron absorption and fission cross sections, contribute to the signals attributed to uranium. In order to investigate possible sources of contamination arising from the presence of other fissionable nuclides the plutonium and americium content of representative samples was determined by conventional alpha spectrometry using surface barrier detectors after the separation of individual radio-nuclides.

\section{Absorption and Leaching Experiments}

Byssal threads of mussels from the BNFL anchor chains are contaminated with various gamma (e. g. ${ }^{106} \mathrm{Ru}$ ) and alpha emitters (e. g. Cm, Pu, Am); aliquots were cleaned to remove sediment and shell debris and then placed in a bromoform alcohol mixture with a density of about $2 \mathrm{~g} \mathrm{~cm}^{-3}$, the light fraction being retained and the heavy fraction discarded. The light fraction representing the purest form of material was initially treated with a $5 \%$ solution of formic acid for 5 min at $20^{\circ} \mathrm{C}$ and then with three separate treatments with $6 \mathrm{NHCl}$ at $90^{\circ} \mathrm{C}$ for $5 \mathrm{~min}$. After each stage of treatment the sample was centrifuged, the residue removed and the alpha and gamma activity determined. The data reported for this experiment are normalised to the loss from $1 \mathrm{~g}$ of byssus, hence a pattern showing no change in levels with treatment indicates uranium is dissolved in direct proportion to the weight of byssal material dissolved, while a decrease in level with treatment indicates loss at a rate much faster than that for bulk sample decomposition.

An experiment using uranium tracer to study the uptake and loss of uranium from byssal material was not possible because of the natural levels of this element in all samples. Instead, another alpha emitting radionuclide was used, namely ${ }^{239} \mathrm{Pu}$. Byssus was treated with sodium hydroxide for $40 \mathrm{~m}$, the insoluble protein separated by centrifugation. Soluble protein was separated from the dissolved material by the addition of ammonium sulphate, and the residue washed with absolute alcohol and dried. Aliquots of both types of protein were added to seawater at $5{ }^{\circ} \mathrm{C}$, stirred for
$24 \mathrm{~h}$ and the residues removed, dried and assayed for alpha activity. In a further experiment samples of fresh byssus were immersed in seawater at $5^{\circ} \mathrm{C}$ spiked with ${ }^{239} \mathrm{Pu}$ and treated in the same manner. Individual $1 \mathrm{-g}$ aliquots of wet surface sediment obtained from the main mussel bed in the Ravenglass Estuary were leached with $50 \mathrm{~cm}^{3}$ of $1 \mathrm{~N}$ solutions of $\mathrm{HCl}_{1} \mathrm{HNO}_{3}$, $\mathrm{H}_{2} \mathrm{SO}_{4}$ and EDTA; after removal of the aqueous phase by filtration each residue was dried and its uranium content determined by the delayed neutron method compared with an untreated aliquot.

\section{RESULTS}

\section{Validation of Radioactivation Methods}

Using samples collected at the BNFL sites, which contained the highest concentrations of non-uranium fissionable radionuclides, namely the transuranics, their contribution to the delayed neutron and fission track methods of uranium assay was determined by experiment and calculation; any contribution from curium was ignored because of the extremely low levels found in all samples. Surface sediments contained between $100-300 \mathrm{pCi} \mathrm{g}-1$ of ${ }^{239} \mathrm{Pu}$ and ${ }^{241} \mathrm{Am}$ with a ${ }^{239} \mathrm{Pu} /{ }^{241} \mathrm{Am}$ ratio of $\sim 1$. Both methods of analysis are concerned with the mass of a particular fissionable species present in a sample, therefore sensitivity of analysis depends upon the mass and fission capture cross section of each nuclide and not its specific radioactivity. The only radionuclides which have been found to be of concern are ${ }^{239} \mathrm{Pu}$ and ${ }^{240} \mathrm{Pu}$, and because it is impossible to differentiate between these by alpha spectometry it is customary to consider them together and assume that they are always present in the same relative proportions; usually the ${ }^{240} \mathrm{Pu}$ is present at less than $30 \%$ of the mixture. The data given in Table 1 clearly illustrate that, for practical purposes, the levels of plutonium present on the most contaminated samples can be ignored. Hence, for the present work the delayed neutron and fission track methods provide acceptable data for the analysis of uranium in the samples. It should be noted, however, that when the fission track method is used to determine the distribution of fissionable species it is not possible to identify fission events arising from specific radionuclides.

A further complication, related to uranium samples from the Ravenglass area derived from BNFL effluent could arise from the presence of uranium with an abnormal isotopic composition; direct measurement of the average isotopic composition of uranium in BNFL effluent are not available. The concentration of uranium in inshore seawater from the Cumbrian and Cornwall coasts have been made by the fission track 
Table 1. Mytilus edulis. Uranium content of various tissues and of some associated materials. Individuals (n $=48$ ) from the Ravenglass Estuary, Cumbria, together with percentage interference arising from the presence of ${ }^{239+240} \mathrm{Pu}$ in samples

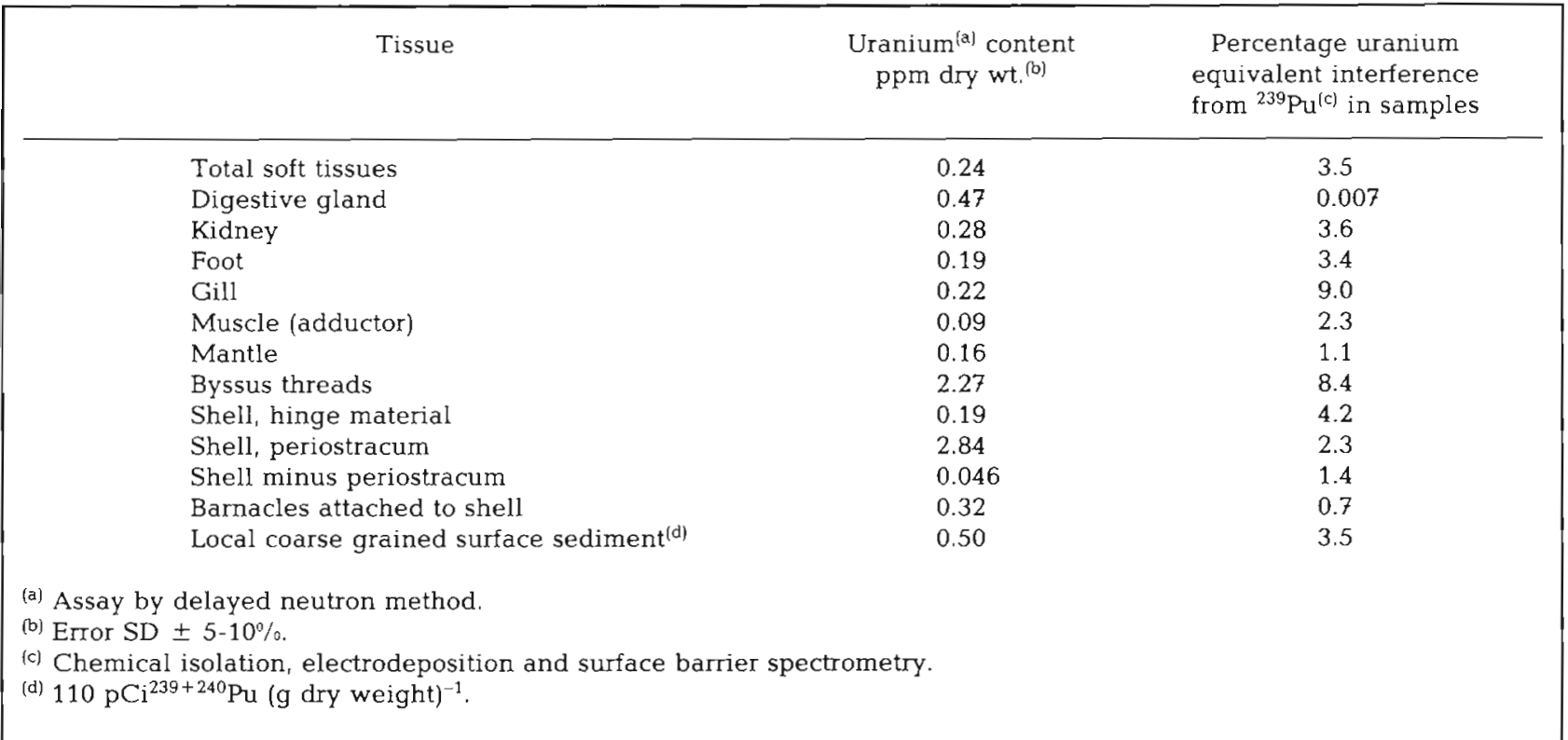

Table 2. Concentration of uranium in filtered seawater sampled at high tide from three sites (see Fig. 1 for localities). The presence of any depleted or enriched uranium arising from

BNFL effluent is not apparent for the Ravenglass sample

\begin{tabular}{|lrr|}
\hline Locality & $\begin{array}{c}\text { Uranium } \\
\text { in filtered seawater } \\
\left(\mu \mathrm{g} \mathrm{l}^{-1}\right)\end{array}$ \\
& & Rean \\
& & Range \\
\hline Ravenglass Estuary (Cumbria) & $2.9 \pm 0.3(\mathrm{n}=4)$ & $2.8-3.5$ \\
Trebarwith (Cornwall) & $3.2 \pm 0.2(\mathrm{n}=5)$ & $2.9-3.4$ \\
Porthcurno (Cornwall) & $3.3 \pm 0.2(\mathrm{n}=5)$ & $2.9-3.5$ \\
& & \\
(") Assay by fission track method. & \\
\hline
\end{tabular}

method using standards of normal isotopic composition and these results are given in Table 2 ; within the errors of measurement the results agree with those obtained for seawater; hence, because of the almost constant concentration of uranium in seawater, the data reported here do not indicate the presence of any significant levels of either enriched or depleted uranium. In a similar manner assay for the concentration of uranium in sediments from the Ravenglass estuary, which are known to be enriched in transuranic debris from BNFL, provides a value of $\sim 2.0$ ppm U dry wt which may be considered normal for nearshore sediments. Data in Table 3 allow comparison of the levels of uranium in natural sediments before and after treatment with various leaching agents which remove uranium associated with the surface of particles or entrained in ferruginous flocs. Acid leaching removes
Table 3. Loss of uranium from the surface of fine-grained sediment of Ravenglass Estuary, Cumbria, following leaching with various agents

\begin{tabular}{|cc|}
\hline Leaching agent & ppm $\mathrm{U}^{(\cdot)}$ dry weight \\
\hline None & 2.21 \\
$1 \mathrm{~N} \cdot \mathrm{HCl}$ & 1.33 \\
$1 \mathrm{~N} \cdot \mathrm{HNO}_{3}$ & 1.37 \\
$1 \mathrm{~N} \cdot \mathrm{H}_{2} \mathrm{SO}_{4}$ & 1.28 \\
$1 \mathrm{~N} \cdot \mathrm{EDTA}$ & 1.78 \\
& \\
\hline & \\
\hline
\end{tabular}

about $40 \%$ of the uranium compared with about $20 \%$ by EDTA. These results indicate that the bulk of uranium is contained within resistant mineral phases; further, there was $a \times 4$ enrichment of uranium in the $<20 \mu \mathrm{m}$ fraction of these sediments which provides most of the mass of resuspended sediment available to the mussel. Indirectly, these results indicate that the uranium in sea water and sediments has a natural isotopic composition, there appears to be no evidence to indicate the presence of substantial quantities of uranium enriched in ${ }^{235} \mathrm{U}$, although the possibility that a component highly depleted in ${ }^{235} \mathrm{U}$ remains to be investigated.

\section{Concentration of Uranium in Mytilus edulis}

The concentration of uranium in various organs of Mytilus edulis are given in Table 4 for mussels col- 
Table 4. Mytilus edulis. Concentration of uranium in various tissues and in some associated materials from Ravenglass Estuary, Sellafield and BNFL effluent anchor chain, Cumbria

\begin{tabular}{|c|c|c|c|}
\hline \multirow[t]{2}{*}{ Tissue } & \multicolumn{3}{|c|}{ Uranium content $t^{{ }^{\circ}}$ (ppm dry weight) } \\
\hline & $\begin{array}{c}\text { Ravenglass } \\
\text { Estuary } \\
\text { January } 1977\end{array}$ & $\begin{array}{c}\text { Sellafield } \\
\text { Beach } \\
\text { October } 1977\end{array}$ & $\begin{array}{l}\text { Sellafield } \\
\text { BNFL effluent pipe } \\
\text { anchor chain } \\
\text { August } 1977\end{array}$ \\
\hline Total soft tissues & 0.24 & - & 0.81 \\
\hline Digestive gland & 0.47 & 0.28 & 1.01 \\
\hline Kidney & 0.28 & - & 0.52 \\
\hline Foot & 0.16 & $<0.10$ & 0.12 \\
\hline Gill & 0.22 & 0.22 & 0.30 \\
\hline Muscle (adductor) & 0.09 & 0.06 & 0.04 \\
\hline Mantle & 0.16 & 0.23 & 0.50 \\
\hline Byssus threads & 2.27 & 3.21 & 3.19 \\
\hline Shell hinge material & 0.19 & 0.11 & 0.60 \\
\hline Shell periostracum & 3.05 & 3.05 & - \\
\hline Shell minus periostracum & 0.046 & 0.085 & - \\
\hline Total shell & - & - & 0.10 \\
\hline Extra pallial fluid & 0.50 & 0.47 & - \\
\hline Barnacles attached to shell & 0.32 & 0.39 & 0.39 \\
\hline Local coarse grained surface sediment & 0.50 & 2.21 & - \\
\hline$(n):$ & $(48)$ & $(49)$ & $(20)$ \\
\hline
\end{tabular}

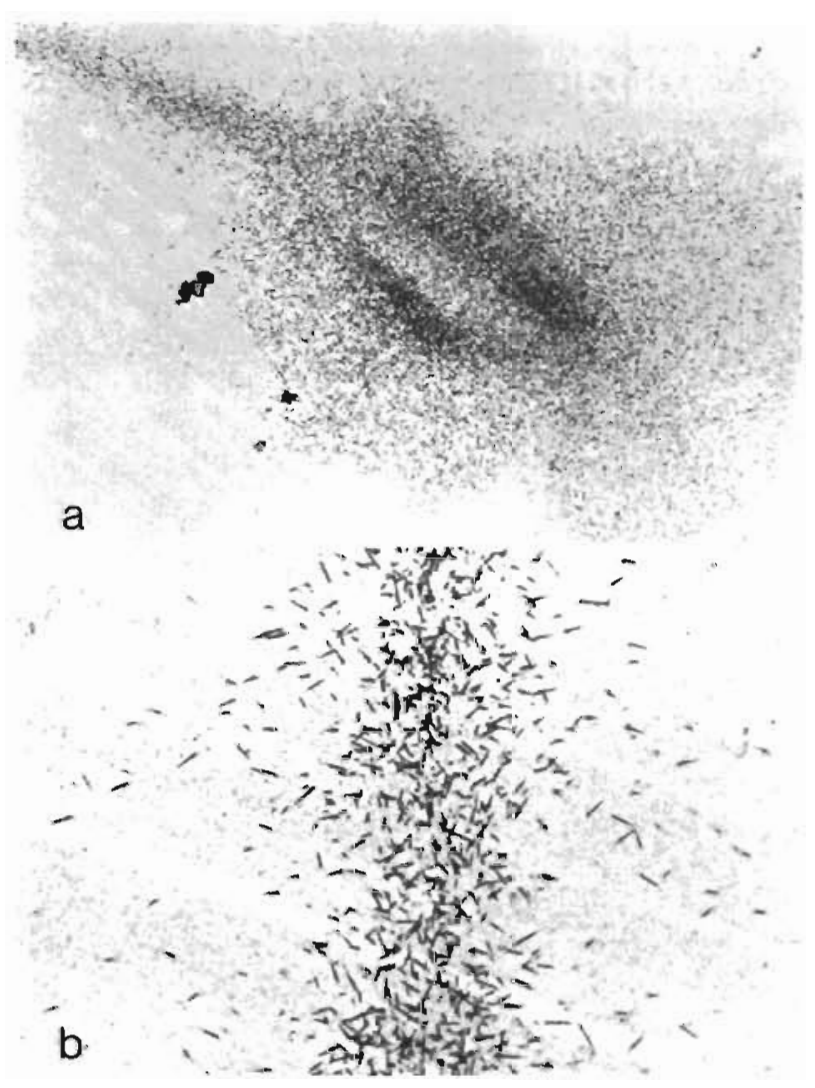

Fig. 2. Mytilus edulis. Distribution of fission tracks in the byssal cap (a) and byssal threads (b) of individuals sampled from the Ravenglass estuary. Track lengths $\sim 10 \mu \mathrm{m}$ lected from the Ravenglass estuary, the Sellafield beach near where the main BNFL effluent pipe enters the sea, and for sub-littoral individuals collected from anchor chains securing the pipe to the seabed. Highest concentrations of uranium were associated with the byssal threads and the periostracum both of which are composed of complex tanned proteins. In the byssal organ the lowest levels of uranium were found in the newly formed byssal threads within the foot region of the mussel, higher levels were found in the emergent threads and the highest in the dense terminal caps to which the mussel is attached to a substrate as illustrated in Figure 2.

Variability in the concentration of uranium along the length of the periostracum in relation to density of this material is illustrated in Figure 3 for samples from the anchor chains; the highest concentrations of uranium were found in the less dense more recent material. The detached periostracum, in transmitted light, contains a complex arrangement of concentric lines formed by different concentrations of pigment, whose distribution is very similar to that of the underlying growth structures found in the shell. In determining the density of the periostracum it was not possible, because of the very small differences in density between lines, to quantify the great detail in line structures present in the most recently formed material.

The lowest levels of uranium were found in pearls, in the periostracum free shell and also in the calcified hinge material joining the valves. Within the shell no 


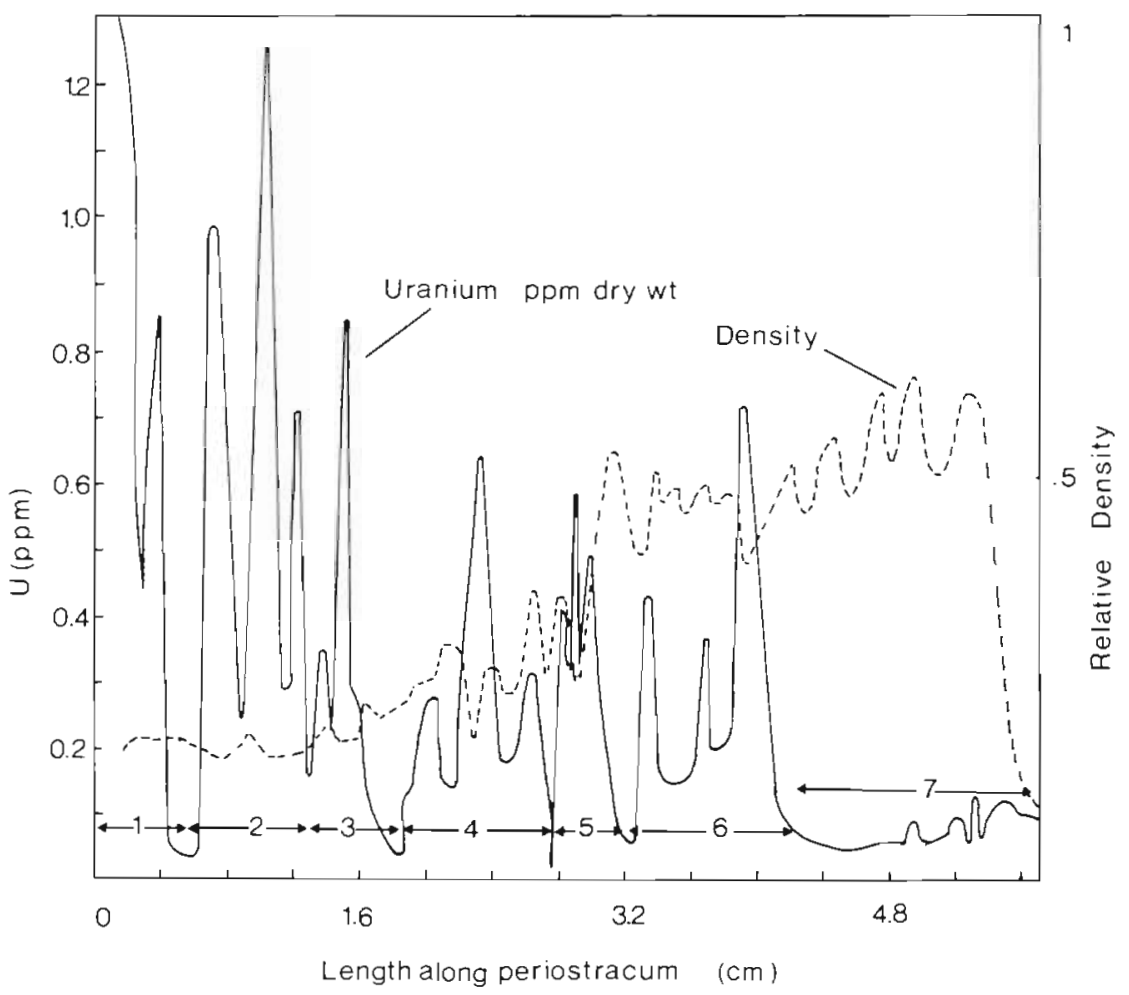

Fig. 3. Mytilus edulis. Variations in concentration of uranium and density of periostracum. BNFL anchor chain sample. The mussel was collected in August 1977 and - on the basis of the frequency of peaks in the uranium curve - associated with three discrete events (at intervals 1-7); these are tentatively related to spring, summer and autumn periods of gonad production. An age of between 7 and 10 years was estimated from the growth structures in the shell. Preliminary evidence indicates that the amplitude of discrete uranium peaks is related to local air temperatures

significant differences were found for the concentration of uranium in aragonitic or calcitic layers. In the soft organs the concentration of uranium showed the following order pericardial gland $>$ digestive gland $>$ kidney $>$ gill $>$ mantle $>$ adductor muscle. The extra pallial fluid contained significant amounts of uranium which may be partly caused by resorption of shell material as a result of anaerobiosis (Lutz and Rhoads, 1977; Gordon and Carriker, 1978) during the three day transport of the mussels from the collection sites to the laboratory when the valves would presumably have remained closed. The concentration of uranium in the style, albeit small, indicates some active uptake by protein with a $50 \%$ loss following $10 \mathrm{~d}$ depuration in laboratory aquaria which can be accounted for by a change in diet and removal of the mussel from natural sources of uranium. It is not considered that the differences observed for the concentration of uranium in littoral and sub-littoral mussels from Cumbria are significant, although some organs from mussels obtained from the anchor chains do contain slightly higher levels of uranium. The concentration of uranium in the adductor muscle of these mussels is low, indicating a small mass transfer of uranium to an organ which has a long turn-over rate relative to most others. A determination of the relative latency of lysosomal activity for some mussels from the anchor chain and the Sellafield beach indicates that those attached to the anchor chains are considerably more stressed, possibly a result of the proximity to the release of the chemical effluent.

\section{Concentration of Uranium in Other Materials}

Pinnotheres pisum (pea crab). Within the limitations of sampling this small crab, present in the mussel as a parasite, the general distribution of uranium follows the same pattern observed for the host with the lowest levels in muscle and the highest in hard tissue (dorsal carapace) which was often covered by ferruginous debris (Table 5).

W in kle and barnacles. The concentration of uranium in both animals were similar; highest levels were found associated with the digestive tracts, and the lowest with the operculum of the winkle.

Marin e alga e. Of the three genera (Fucus, Ulva, Corallina) of marine algae studied the highest concentrations of uranium were associated with living Corallina officinalis; lower levels were found in dead 
material which was devoid of an external organic coating.

\section{Distribution of Uranium in Mytilus edulis and in Associated Materials}

The distribution of fission tracks (i.e. uranium) emitted from thin sections of biological material, and recorded in dielectric detectors attached to the thin sections during neutron irradiation, provides information for the distribution of total fissionable nuclides which, to a first order of approximation for this study, is taken to reflect the distribution of uranium. When track density and distributions are compared from samples containing transuranic nuclides with those containing only uranium the general distribution of track densities are very similar. With very few exceptions the hot spots of activity have mean diameters of between 5-50 $\mu \mathrm{m}$ (mainly in the stomach and intestine) which tend to be aggregates rather than single particles.

\section{Proteinaceous Materials}

Bys a l m a t e ri a l. For purposes of this report the following materials are identified, the white gland which secretes the byssal threads which are terminated by the byssal cap; the 'purple gland' (Brown, 1952), which secretes a substance which reacts with the newly-formed byssal thread within the foot structure of the mussel and tans the byssal threads. The newly-formed threads consist predominantly of protein and contain very low track densities in the region where the threads emerge from the foot and presumably where they are tanned. The track density then increases and for the rest of the thread where they are high and homogeneously distributed with an absence of hot spots. The terminal caps contain the highest concentration of tracks which have a homogeneous distribution; the increase in track density is attributed to the thick nature of this structure. In several experiments attempts were made to section $(t / s, 1 / s)$ parts of a thread to determine whether or not tracks originated from the surface or within the matrix of the material; the results were inconclusive because of smearing during the preparation of samples. A low track density was observed for the white gland but some enhancement for the associated purple gland responsible for the tanning process. In comparing histological features between the white and purple glands, the latter contained a higher density of staining for SS-SH and disulphide groups. Data are given in Table 6 for uranium content of various parts of byssal threads.

Periostra cu m. A general diffuse distribution of tracks with a pronounced correlation between track density and zonal line structures was noted. Hot spots were rarely observed but when present they tended to be associated with bands of granular pigmentation.

F o o t. With the exception of the purple gland track densities were low except for epidermal cells, especially pigmented external surfaces, which also contained SS-SH and disulphide ligands.

Table 5. Concentration of uranium in Pinnotheres pisum, Littorina, marine algae and local sediment from Ravenglass Estuary, Cumbria (March 1977) determined by fission track and delayed neutron methods

\begin{tabular}{|c|c|c|}
\hline Sample & $\begin{array}{l}\text { Uranium (ppm dry weight) }{ }^{(\cdot)} \\
\text { Fission track method }\end{array}$ & $\begin{array}{l}\text { Delayed neutron } \\
\text { counting }{ }^{\left({ }^{\prime}\right)}\end{array}$ \\
\hline Pinnotheres pisum: total body & 0.09 & 0.11 \\
\hline Pinnotheres pisum: muscle (leg) & 0.06 & - \\
\hline Pinnotheres pisum: gut & 0.25 & - \\
\hline Pinnotheres pisum: carapace (dorsal) & 0.39 & 0.34 \\
\hline Pinnotheres pisum: faeces & 0.21 & - \\
\hline Littorina (winkle): total soft tissue & 0.38 & - \\
\hline Littorina (winkle): digestive gland & 0.47 & - \\
\hline Littorina (winkle): distal portion gut & 1.12 & - \\
\hline Littorina (winkle): operculum & 0.27 & - \\
\hline Marine algae: Fucus vesiculosus & 0.10 & 0.12 \\
\hline Marine algae: Ulva sp. & 0.22 & 0.26 \\
\hline Marine algae: Corallina officinalis (alive) & 0.62 & 0.68 \\
\hline Marine algae: Corallina officinalis (dead) & 0.11 & 0.08 \\
\hline Local fine-grained sediment: total & 2.21 & 2.32 \\
\hline Local fine-grained sediment: $<20 \mu \mathrm{m}$ fraction & 4.05 & - \\
\hline Local fine-grained sediment: $>20 \mu \mathrm{m}$ fraction & 0.91 & - \\
\hline $\begin{array}{l}\text { (") Error } \mathrm{SD} \pm 10 \% \\
(\cdots) \text { Error } \mathrm{SD} \pm 5-10 \%\end{array}$ & & \\
\hline
\end{tabular}


Table 6. Mytilus edulis. Micro-distribution of uranium determined by the fission track method in tissues. Ravenglass Estuary, Cumbria, January 1977

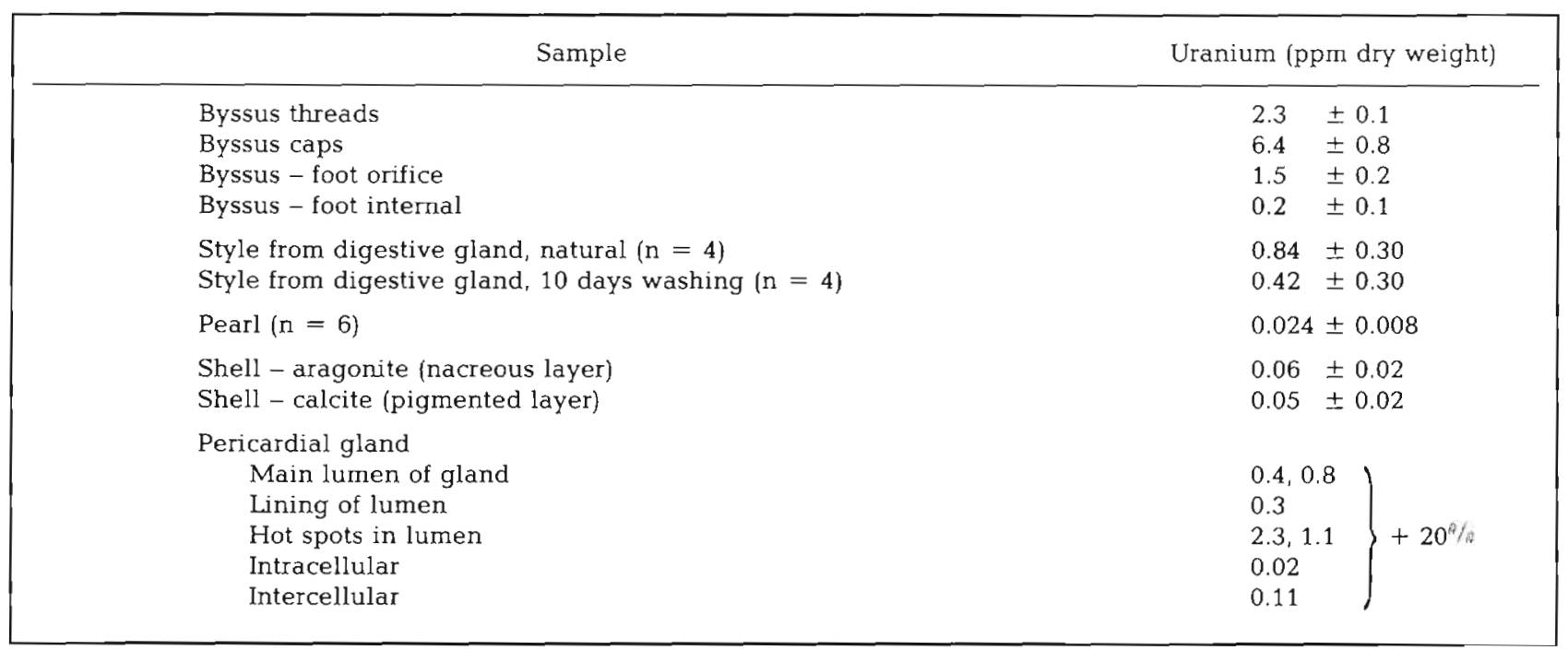

Sty le. A protein rich material secreted by the style sac within the stomach of the mussel which provides enzymatic secretions for digestion of food. As the food enters this region, contained in a string of mucus, it is brought into intimate contact with the style which also aids digestion by mechanical action. Hence the style is exposed to uranium enriched particulate material but, as shown in Table 6 , it contains very little uranium. As the mass of the style changes with requirements for digestion, the result for $10 \mathrm{~d}$ depuration in an aquarium possibly reflects a decrease in uranium content of food. The style contained very low track densities and hot spots were absent. No correlation between the density of tracks in the bulk protein and the lacunae-like spaces between the concentric ring structures of this organ were observed. There was, however, a slight increase in track density associated with pigmented granular material present in the lacunae.

\section{Digestive Gland}

Within this organ a distinct association of fission and alpha tracks and aggregates of particulate debris was observed, especially in the mid-gut region; the highest concentrations were found in the crypts of villi and brown cells of the internal digestive gland epithelium of the stomach and intestine. Examples of track distributions in the digestive gland are given in Figure 4.

\section{Kidney and Pericardial Glands}

Both organs are considered to perform excretory functions and a pronounced association of tracks was observed localised upon internal surfaces somewhat reminiscent of the human kidney. The kidney region contained small opaque granules, generally $<1 \mu \mathrm{m}$ mean diameter, formed of sequestered materials which can contain high concentrations of various elements, especially calcium. The optical resolution employed was insufficient to determine whether or not these granules were enriched in uranium, but it cannot be very high otherwise the granules would be associated with pronounced hot spots which were rarely observed. The pericardial gland is situated within the pericardial cavity, containing the heart, and performs a function similar to that of the kidney. The data given in Table 6 indicate that uranium is associated with the walls of lumen and also enriched in granular aggregates commonly present in this gland.

\section{Gills}

A general diffuse distribution of tracks is associated with occasional hot spots, possibly related to particulate debris.

$$
\text { Mantle, Gonads }
$$

A general diffuse distribution of tracks occurred and in some individuals lower densities were associated with mature oocytes. Similarly in regions where the blind tubules of the digestive gland penetrate the mantle track densities were low.

\section{Hard Tissues}

Very low track densities for shell material were observed when the periostracum had been removed 


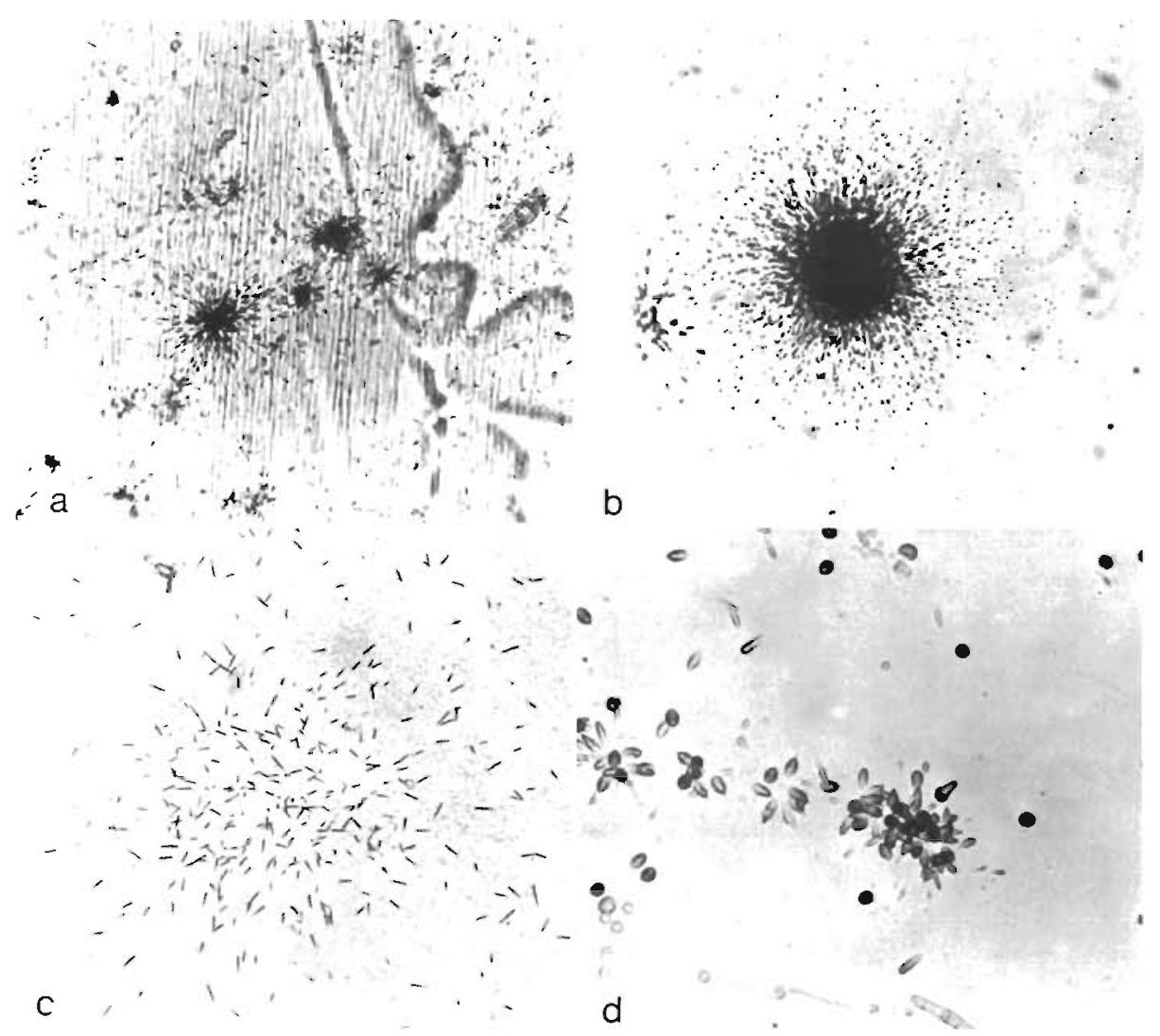

Fig. 4. Mytilus edulis. Fission tracks from uranium in digestive gland. (a, b) Hot spot illustrating high density of tracks originating from particles; (c) diffuse distribution of tracks; (d) localised area of high activity

and the same feature was found for pearls whether they originated from the inner nacreous layer of the shell or from within mantle tissue. Data are given in Tables 4 and 6 for uranium content of shell and pearl.

$\mathrm{H}$ in $\mathrm{g} \mathrm{e}$. Because of the hardness of hinge material it was difficult to prepare suitable thin sections; by using polished thick hinge sections it was observed that there was an approximately two-fold increase of tracks along the edges which were attached to the shell valves because of the presence of tanned protein materials.

\section{Fucus vesiculosis}

Both $t / s$ and $1 / s$ thin sections contained a homogeneous distribution of tracks and any pronounced concentration associated with external surfaces was not apparent. A few localised hot spots were associated with the conceptacles and at the edge of some parts of the thallus; whether or not this was due to the presence of occluded particulate debris is not known. Within the cells the tracks tended to be associated with the lining of cell walls and also distributed throughout cell contents.

\section{Sediment}

Sedimentary material to which the mussel has access was examined by sampling debris adhering to its external body surfaces and algae. With the exception of fragmented parts of byssal threads, which were easily recognised from track distributions, the remaining materials consisted of opaque to semi-opaque debris and sand grains ( $\sim 70 \%$ by volume) occluded in a ferruginous floc. Apart from a general diffuse distribution of tracks the main feature observed was the presence of intense hot spots associated with particulate materials as illustrated in Figure $4 \mathrm{~b}$; particle size varied between $\sim 1$ and $100 \mu \mathrm{m}$.

\section{Depuration Experiments}

Loss of uranium from mussels collected in the Ravenglass and Lynher estuaries was examined after depuration times of 4 and 7 d respectively as illustrated in Table 7 . The overall loss of uranium is attributed to the gradual removal of particulate phase faeces with very little loss, if any, from bound sites such as those in 
Table 7. Loss of uranium from Mytilus edulis and barnacles from Ravenglass and Lynher Estuaries following depuration in recirculating water laboratory aquaria. All values expressed as $\mathrm{U}$ ppm dry weight ${ }^{(1)}$

\begin{tabular}{|c|c|c|c|c|}
\hline \multirow[t]{2}{*}{ Sample } & \multicolumn{2}{|c|}{$\begin{array}{c}\text { Ravenglass } \\
\text { Estuary }\end{array}$} & \multicolumn{2}{|c|}{$\begin{array}{l}\text { Lynher } \\
\text { Estuary }\end{array}$} \\
\hline & Natural & $\begin{array}{l}4 \text { days } \\
\text { washing }\end{array}$ & Natural & $\begin{array}{c}7 \text { days } \\
\text { washing }\end{array}$ \\
\hline Total soft tissue & 0.24 & 0.14 & 0.11 & 0.16 \\
\hline Digestive gland & 0.47 & 0.27 & 0.83 & 0.41 \\
\hline Kidney & 0.28 & 0.44 & - & - \\
\hline Mantle & 0.16 & 0.17 & 0.38 & - \\
\hline Gill & 0.25 & 0.11 & - & - \\
\hline Foot & 0.19 & $<0.1$ & 0.43 & - \\
\hline Muscle (adductor) & 0.09 & 0.10 & - & - \\
\hline Byssus threads & 2.27 & 2.94 & 4.23 & 4.10 \\
\hline Shell & 0.046 & 0.035 & 0.079 & 0.12 \\
\hline Barnacles & 0.32 & 0.27 & 0.68 & 0.51 \\
\hline Aquaria debris & - & 3.95 & - & - \\
\hline
\end{tabular}

mantle, muscle and byssal threads. A problem encountered in this study was the recirculation of finely divided faecal debris in the aquaria.

\section{Leaching and Absorption Experiments}

Data are given in Figure 5 for the loss on leaching of total alpha particle radioactivity and ${ }^{106} \mathrm{Ru}$ from byssal threads sampled from the BNFL anchor chains. The alpha particle activity curve shows that the loss of this element is proportional to the solution of the byssal material whereas the loss of ruthenium activity proceeds at a much faster rate and hence indicates either the removal from surfaces or selective leaching from depth.

In a further study, mussels from the Ravenglass estuary were placed in an aquarium and over a period of 3 months the byssus was harvested every $4 \mathrm{~d}$ to determine whether or not any change in uranium levels could be observed. The results were inconclusive, possibly because of the uptake of naturally occurring uranium in seawater and the recirculation by faecal debris. Because of the high concentration of uranium in natural byssal threads any spiking experiments were not practical. In order to pursue this topic further, soluble and insoluble fractions of byssal protein exposed to ${ }^{239} \mathrm{Pu}$ tracer were added to seawater; after $24 \mathrm{~h}$ exposure with continuous stirring, approximately $70 \%$ of the plutonium was taken up equally on both fractions of protein which could easily be removed by leaching with dilute acid. Finally to test the hypothesis of uptake of elements by absorption, fresh byssal

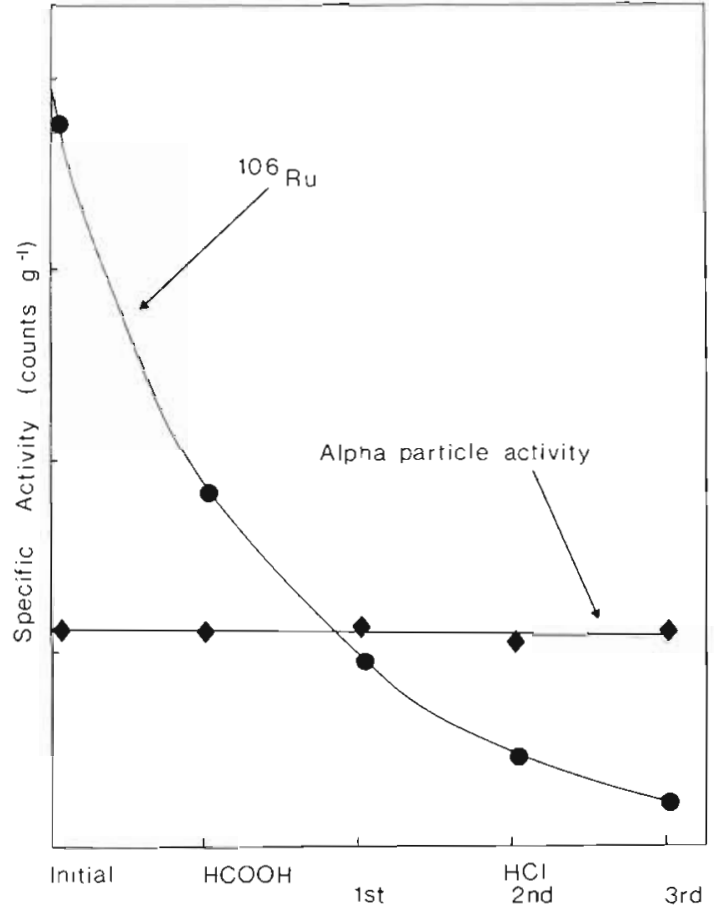

Fig. 5. Loss of ${ }^{106} \mathrm{Ru}$ and alpha particle activity from byssus following treatment with aliquots of formic acid and three separate treatrnents with hydrochloric acid

threads were exposed to plutonium in seawater and once more over a period of $24 \mathrm{~h}$ the uptake of tracer was $70 \%$ indicating an ability of the surface of the byssal thread to bind this element.

\section{DISCUSSION}

An objective assessment of the manner in which uranium enters Mytilus edulis, and participates in physical, biological and biochemical processes, as well as the sites of uranium retention and the rates of loss through renal and faecal excretion and the role of byssal threads must wait until more is known concerning essential processes associated with the relevant organs; some of these problems have been identified by Bayne (1976). This investigation has shown that a significant source of uranium is from diet, although some is also likely to be taken up directly from seawater. Dietary intake is reflected by uranium levels found in the digestive gland and associated organs; uranium transported across membranes and that entering the systematic circulation of the mussel is mainly removed through the excretory organs. The ratio of loss by renal or faecal excretion is not known. Relative to most organs the highest levels of uranium are found associated with the periostracum and byssal threads. Both consist of proteins which have been tanned and a 
possible correlation between the presence of SS-SH and disulphide groups and uranium has been noted. This association is a little unusual as the chemical characteristics of uranium are not normally associated with chalcophilic tendencies and, therefore, uptake of uranium in relation to sulphur compounds would seem to be through an attraction to suitable groups rather than the direct formation of stable uranium compounds with sulphur. In the tanned proteins the distribution of fission tracks clearly indicates a homogeneous distribution, hot spots are rare, hence either the uranium enters the tanned proteins in a homogeneous manner or is being evenly absorbed onto the surfaces of such materials.

Results of laboratory depuration experiments, illustrated in Table 8, indicate no significant change occurred for the concentration of uranium in byssal threads (although some elements, e. g. La, Ba, Mo, Nb, Zr, As, $\mathrm{Cu}, \mathrm{Ni}, \mathrm{Mn}, \mathrm{Cr} . \mathrm{V}, \mathrm{F}$ were lost) which could be accounted for by a lack of growth in captivity, and saturation by uranium.

Identification of the chemical composition of tanning agents is poorly understood, but Brown (1952), Tamarin (1975), and Tamarin et al. (1976) have described some of the processes. Chipman and Schommers (1968) and Vitellaro-Zuccarello (1973) have reported the presence of fungal hyphae on the byssal apparatus of Mytilus galloprovincialis which would provide admirable surfaces for uranium uptake; within the resolution of about $5 \mu \mathrm{m}$, afforded by the fission track studies, no correlation with such features, if present, was observed. A number of workers, for example, Bryan et al. (1966), Lucu et al. (1969), Shimizu et al. (1971), Fowler et al. (1975) and Suzuki et al. (1975) have concluded that the uptake of a number of elements by the byssus is through surface absorption, on occasions qualification is made that no physiological processes are involved (e. g. Shimizu et al., 1971) while reference is also made to various vague binding properties of the surface of shells to account for the accumulation of some elements. Examination of thin sections of marine algae indicate that most of the uranium is evenly distributed throughout the tissues.

In the tissues of the mussel there is a pronounced association between uranium and cell surfaces and, with the exception of particulate material in stomach and intestine, hot-spots of radioactivity tend to be associated with surfaces, within diverticula, and sacs. In the kidney, uranium is noticeably associated with the linings of tubules and sacs and possibly reflects the breakdown of dissolved components giving rise to non-diffusable proteins which would then accumulate in the organs followed by secretion through the renal duct; in this investigation uranium enrichment in kidney granules (Coombs and George, 1978) does not appear to be very significant but granules enriched in uranium were observed in the pericardial gland.

Hard tissues of the mussel contain very little uranium; this is in agreement with observations of Tatsumoto and Goldberg (1959). Schroeder et al. (1970) have commented that trace element distributions, including those of uranium, are determined primarily by biological processes. In this investigation the possibility is considered of using uranium associated with growth lines in the periostracum as a record of past performance of the mussel in relation to uptake of uranium from ambient levels in seawater.

In spite of the local release of uranium in the BNFL effluent (often in considerable quantities) no pronounced enrichment of uranium in mussels or local seawater was observed, although mussels living on the effluent pipeline contain slightly more uranium than those from littoral sites of the area; mussels sampled distant from sources containing industrial uranium effluents may even contain more uranium. Hamilton (1978) has studied the distribution of some transuranium radionuclides and of ${ }^{137} \mathrm{Cs}$ in a dated (1954-1978) arenaceous sediment core from the Ravenglass estuary and determined the distribution of

Table 8. Mytilus edulis. Loss of some elements from byssal threads following retention in a laboratory recirculating water aquarium for $52 \mathrm{~d}$. Ravenglass Estuary (Cumbria) and Trebarwith Strand (Cornwall). All values expressed as ppm dry weight ${ }^{\circ}{ }^{\circ}$

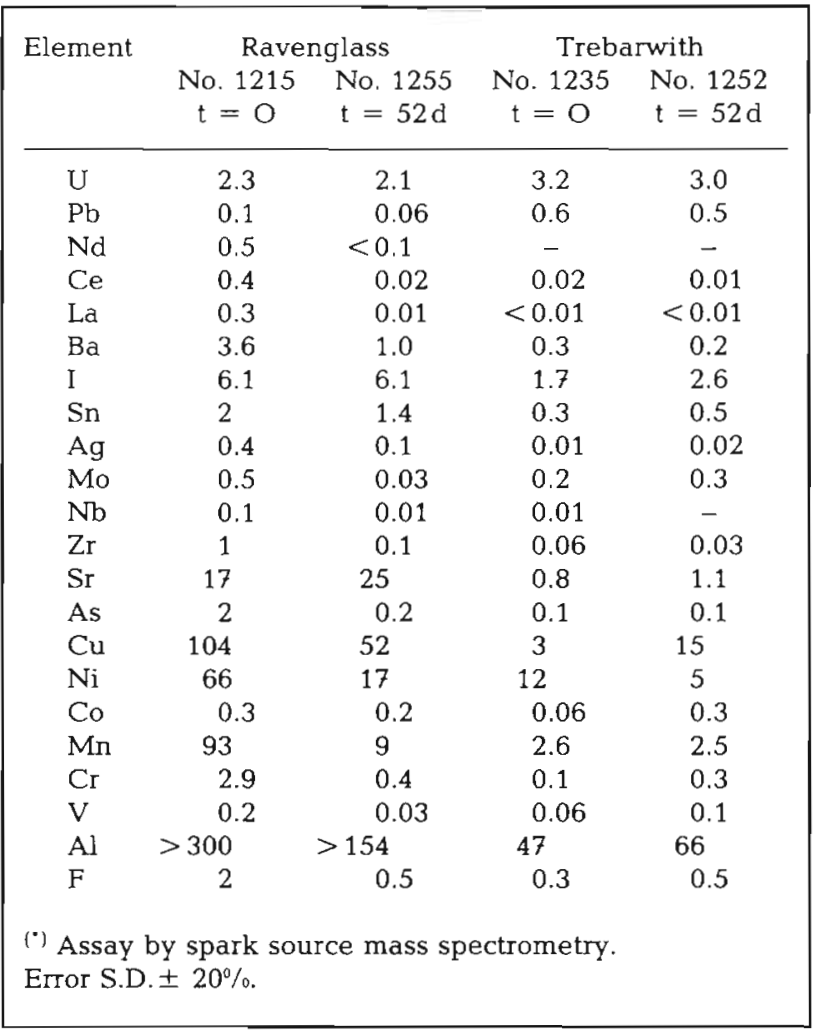




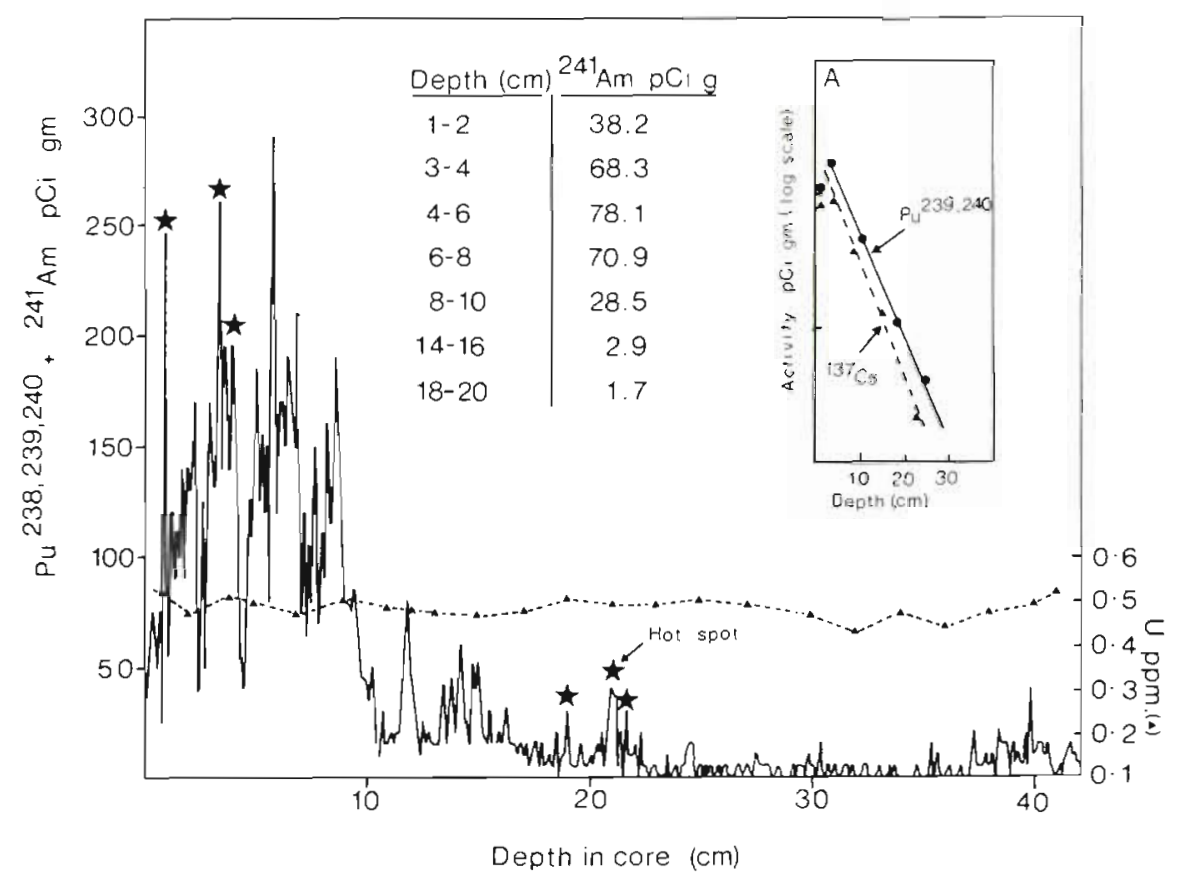

Fig. 6. Variability in the concentration of some transuranium elements and ${ }^{137} \mathrm{Cs}$ in a dated sediment core profile from consolidated sediments of Ravenglass estuary compared with constant values for uranium

uranium with depth; the results, illustrated in Figure 6, clearly reveal that - while the radionuclides from the B.N.F.L. effluent show a depth distribution compatible with known releases of the various radionuclides - the concentration of uranium remains constant.

Uranium and the transuranics present in the BNFL effluent originate from reprocessing uranium fuel elements and initially the transuranic elements will be contained within particles of uranium oxide. From a consideration of the $\mathrm{Pu} / \mathrm{Am}$ ratios in hot particles separated from sediments of the Ravenglass estuary both Pu and Am do not appear to become significantly separated in the marine environment.

In some preliminary measurements, by alpha spectrometry on isolated radioactive hot-particles, the presence of uranium is occasionally identified; this may reflect the length of time individual particles entering the Irish Sea have been immersed in seawater. If the digestive gland of the mussel does contain uranium particles originating from BNFL effluent then, as the gross assay for uranium does not show abnormally high levels, the particles must be extremely small. Nowhere in the Ravenglass estuary have high concentrations of uranium (and transuranics) been found associated with natural heavy mineral concentrates, hence it is concluded that a combination of particle size and density is insufficient for the particulate transuranics to follow natural concentration pathways. Both uranium and the transuranics are concentrated in the finest particle size fractions $(0.1-3 \mu \mathrm{m}$ M.P.D.) of the sediments and both are noticeably associated with hot spots, although there is also a diffuse distribution.

Considering the observed distributions of these elements it seems possible that they are controlled by a separate process, namely the adsorption and coprecipitation of any dissolved forms onto a third chemical species common to the area. Of the many possibilities, and acknowledging the interactive nature of uranium and the transuranics with resuspension of sediments and iron floculation processes, together with adsorbing colloid flotation (Williams and Gillam, 1978), a candidate for a chemical process would be coprecipitation with barium sulfate (Sill, 1969) especially for uranium in the quadrivalent state. The sediments of the Ravenglass estuary contain between 900-2000 ppm dry wt of barium (together with $10-150$ ppm total rare earth elements) and therefore, scavenging of uranium and transuranium elements would be by coprecipitation and absorption; hence uranium and the transuranics are not likely to concentrate with heavy mineral phases but rather remain suspended with the finer sedimentary debris which is of correct size for intake by the mussel.

\section{Addition at Proof Stage}

Recently, Pirie and George have shown that the podocyte of the mammalian kidney is similar to the pericardial gland of the mussel concerned with 
ultrafiltration processes, while the kidney performs resorption and secrectory functions. There are enhanced levels of uranium in the kidney of the mussel, but uranium-enriched granules are absent. Levels of uranium in the pericardial gland are greater than those of the kidney and are associated with granular bodies which could be formed as a result of ultrafiltration as occurs in the mammalian kidney. - Pirie, B. J. S., George, S. G. (1978). J. mar. biol. Ass. U. K. 59: 819-829

Acknowledgements. I am grateful to Mr. H. Longley and Mr. D. Bratt of B.N.F.L. for providing some of the samples of mussel $_{i}$ to Mr. R. J. Clifton, Mr. D. M. Lowe, Dr. M. N. Moore, and Dr. B. L. Bayne for useful discussions. The Institute for Marine Environmental Research is a component of the Natural Environmental Research Council.

\section{LITERATURE CITED}

Amiel, S. (1962). Analytical applications of delayed neutron emission in fissionable elements. Analyt. Chem. 34: 1683-1972

Bayne, B. L. (ed.) (1976). Marine mussels, their ecology and physiology, Cambridge University Press (Intemational Biological Programme 10)

Brown, C. H. (1952). Some structural proteins of Mytilus edulis. Q. Jl Microscop. Sci. 93: 487-502

Bryan, S. W., Preston, A., Templeton, W. L. (1966). Accumulation of radionuclides by aquatic organisms of economic importance in the U. K. In: Disposal of Radioactive Wastes into Seas, Oceans and Surface Waters. IAEA, Vienna. pp. 623-637

Chipman, W., Schommers, E. (1968). Role of surface-associated organisms in the uptake of radioactive nuclides by the clam Tapes decussatus. Radioactivity in the Sea. IAEA Publ. 24: 1-11

Coombs, T. L., George, S. G. (1978). Mechanisms of immobilisation and detoxification of metals by marine organisms. In: McLusky, D. S., Berry, A. J. (eds) Physiology and behaviour of marine organisms. Pergamon Press, Oxford. pp. $179-187$

Fowler, S., Heyraud, M., Beasley, T. M. (1975). Experimental studies on plutonium kinetics in marine biota. In: Impacts of nuclear releases into the aquatic environment. IAEA, Vienna. pp. 157-177

Gordon. J., Carriker, M. R. (1978). Growth lines in a bivalve mollusc: subdaily patterns and dissolution of the shell. Science, N. Y. 202: 519-521
Hamilton, E. I. (1966). The determination of uranium in rocks and minerals by the delayed neutron method. Earth Planet. Sci. Lett. 1: 77-81

Hamilton, E. I. (1971). The concentration and distribution of uranium in human skeletal tissues. Calc. Tissue Res. 7: 150-162

Hamilton, E. I. (1978). The application of novel methods to determine the concentration and distribution of alpha emitters in environmental materials. In: Symposium on the Determination of Radionuclides in Environmental and Biological Materials. Central Electricity Generating Board, London

Lucu, C., Jelisavčić, Lulić, S., Strohal, P. (1969). Interactions of ${ }^{233} \mathrm{~Pa}$ with tissues of Mytilus galloprovincialis and Carcinus mediterraneus. Mar. Biol. 2: 103-104

Lutz, R. A., Rhoads, D. C. (1977). Anaerobiosis and a theory of growth line formation. Science, N. Y. 198; 1222-1227

Moore, M. N., Lowe, D. M., Fieth, P. E. M. (1978). Responses of lysosomes in the digestive cells of the common mussel, Mytilus edulis, to sex steroids and cortisol. Cell Tiss. Res. 188: $1-9$

Schroeder, J. H., Miller, D. S., Friedman, G. M. (1970). Uranium distributions in recent skeletal carbonates. J. sedim. Petrol. 40: 672-681

Shimizu, M., Kajihara, T., Suyama, I., Hiyama, Y. (1971). Uptake of ${ }^{58} \mathrm{Co}$ by the mussel Mytilus edulis. J. Radiat. Res. $12: 17-28$

Sill, C. W. (1969). Separation and radiochemical determination of uranium and the transuranium elements using barium sulfate. Hlth. Phys. 17: 89-107

Suzuki, H., Koyanagi, T., Saiki, M. (1975). Studies on rareearth elements in seawater and uptake by marine organisms. In: Impacts of Nuclear Releases into the Aquatic Environment. IAEA Vienna. pp. 77-91

Tamarin, A. (1975). An ultrastructural study of byssus stem formation in Mytilus californianus. J. Morph. 145: 151-178

Tamarin, A., Lewis, P., Askey, J. (1976). The structure and formation of the byssus attachment plaque in Mytilus. J. Morph. 149: 199-222

Tatsumoto, M., Goldberg, E. D. (1959). Some aspects of the marine geochemistry of uranium. Geochim. Cosmochim. Acta 17: 201-208

Vaughan, J. (1973). Distribution, excretion and effects of plutonium as a bone-seeker. In: Hodge, H. C., Stannard, J. N., Hursh, J. B. (eds). Handbook of Experimental Pharmacology XXXVI. Uranium, Plutonium Transplutonic Elements. Springer, Berlin. pp. 248-502

Vitellaro-Zuccarello, L. (1973). Ultrastructure of the byssal apparatus of Mytilus galloprovincialis. I. Associated fungal hyphae. Mar. Biol. 22: 225-230

Williams, W. J., Gillam, A. H. (1978). Separation of uranium from seawater by adsorbing colloid formation. Analyst, Lond. 103: 1239-1243 